\title{
Progress in Clinical Neurosciences: Therapeutic Hypothermia in Severe Traumatic Brain Injury
}

\author{
David A. Zygun, Christopher J. Doig, Roland N. Auer, Kevin B. Laupland, \\ Garnette R. Sutherland
}

\begin{abstract}
Severe traumatic brain injury (sTBI) is a relatively common problem with few therapies proven effective. Despite its use for over 50 years, therapeutic hypothermia has not gained widespread acceptance in the treatment of sTBI due to conflicting results from clinical trials. This review will summarize the current evidence from animal, mechanistic and clinical studies supporting the use of therapeutic hypothermia. In addition, issues of rewarming and optimal temperature will be discussed. Finally, the future of hypothermia in sTBI will be addressed.
\end{abstract}

RÉSUMÉ: Hypothermie thérapeutique dans les traumatismes crâniens sévères Le traumatisme crânien sévère (TCS) est un problème relativement fréquent pour lequel peu de traitements se sont avérés efficaces. Bien que l'hypothermie thérapeutique soit utilisée depuis 50 ans, des essais cliniques dont les résultats sont discordants ont entravé son utilisation dans le traitement du TCS. Cette revue résume les données actuelles des études chez l'animal et chez l'humain ainsi que les études sur les mécanismes en cause appuyant son utilisation. De plus, le réchauffement et la température idéale sont discutés. Finalement, l'avenir de l'hypothermie dans le traitement du TCS est abordé.

Can. J. Neurol. Sci. 2003; 30: 307-313

Severe traumatic brain injury (sTBI) is relatively common with an estimated incidence of 86 to over 300 cases per 100,000 per year. ${ }^{1}$ It is a devastating problem with few proven therapies. Although Fay ${ }^{2}$ first proposed the use of therapeutic hypothermia in the setting of severe traumatic brain injury in 1943, the largest clinical trials have not demonstrated benefit despite promising initial results from animal and clinical phase II trials. In addition to summarising the mechanistic animal model evidence, this review will critique the recent clinical evidence and highlight the specific issues of rewarming and optimal temperature.

\section{EXPERIMENTAL EVIDENCE}

The protective effect of hypothermia has been demonstrated in various animal models of traumatic brain injury (Table 1). Clifton et $\mathrm{al}^{3}$ reported a pretreatment study where adult rats treated with transient hypothermia $\left(30^{\circ} \mathrm{C}\right)$ for one hour beginning prior to fluid percussion (F-P) brain injury exhibited better functional outcome (beam walking and beam balance) than normothermic controls. In addition, mortality was lower in the hypothermia treated rats. Palmer and colleagues ${ }^{4}$ also demonstrated the beneficial effects of transient hypothermia $\left(32^{\circ} \mathrm{C}\right)$ for two hours prior to controlled cortical trauma in a rat model. Hypothermia reduced lesion volume at two weeks. As premorbid therapeutic hypothermia is not a clinical option, much attention has been focused on the timing of initiation of therapy.
Lyeth et $\mathrm{al}^{5}$ reported that posttraumatic hypothermia improved behavioural outcome when initiated within 15 minutes but not 30 minutes after trauma. In a parasagittal F-P model, posttraumatic application of moderate hypothermia $\left(30^{\circ} \mathrm{C}\right)$ begun within five minutes and lasting for three hours improved histopathological and cognitive outcome. ${ }^{6}$ Others have obtained similar results. ${ }^{7}$ In cats, mild $\left(33^{\circ} \mathrm{C}\right)$ as opposed to moderate $\left(29^{\circ} \mathrm{C}\right)$ hypothermia proved optimal in reducing lesion size and extracellular glutamate overflow in epidural balloon compression of brain. ${ }^{8}$ In dogs, hypothermia to $31^{\circ} \mathrm{C}$ reduced intraventricular pressure, but not lethal brain edema of rewarming, after temporary epidural brain compression. ${ }^{9}$ Similarly, Pomeranz et al ${ }^{10}$ found intracranial pressure and lesion size after brain compression were reduced by hypothermia to $31^{\circ} \mathrm{C}$ for five hours, followed by $35^{\circ} \mathrm{C}$ up to $62 \mathrm{hrs}$. Hypothermia has also been shown to be effective in primates after experimental brain trauma. ${ }^{11}$

From the Departments of Medicine (DAZ, KBL), Critical Care Medicine (KBL, CJD), Community Health Sciences (CJD), Clinical Neurosciences (GRS, RNA), and Pathology and Laboratory Medicine (RNA), University of Calgary, Calgary, Alberta, Canada.

Received SePtember 9, 2002. ACCePted infinalform April 21, 2003. Reprint requests to: Garnette Sutherland, Head, Division of Neurosurgery, Rm: MRG008 - Foothills Medical Centre, University of Calgary, 1403 29th Street, NW, Calgary, AB T2N 2T9 Canada. 
Table 1: Experimental evidence regarding hypothermia in traumatic brain injury

\begin{tabular}{|c|c|c|c|c|c|c|}
\hline Species & Pre & Post & Temp. $\left({ }^{\circ} \mathrm{C}\right)$ & Duration (hrs.) & Model & Measure/Effect \\
\hline $\mathrm{Rat}^{3}$ & + & & 30 & 1 & fluid percussion & behaviour, mortality improved \\
\hline $\mathrm{Rat}^{4}$ & + & & 32 & 2 & cortical impact & lesion volume improved \\
\hline Rat $^{5}$ & & + & 30 & 1 & fluid percussion & behaviour improved \\
\hline $\operatorname{Rat}^{6,7}$ & & + & 30 & 3 & fluid percussion & lesion volume, behaviour improved \\
\hline Rat $^{14}$ & & + & 30 & 1 & $\begin{array}{l}\text { impact-acceleration trauma } \\
+2^{\circ} \text { insults hypoxia/hypofusion }\end{array}$ & hypothermia protected against secondary insults \\
\hline $\operatorname{Rat}^{15}$ & & + & 32 & 4 & $\begin{array}{l}\text { direct metal impact, } \\
\text { secondary hypoxia }\end{array}$ & motor, cognitive performance not improved \\
\hline $\mathrm{Cat}^{8}$ & & + & 33,29 & & compression by epidural balloon & extracellular glutamate, lesion size decreased \\
\hline $\operatorname{Dog}^{9}$ & & + & 31 & 48 & epidural compression & intracerebral pressure decreased \\
\hline $\operatorname{Dog}^{10}$ & & + & 31 , then 35 & 5,57 & brain compression & lesion volume, intracranial pressure decreased \\
\hline
\end{tabular}

Thus, therapeutic hypothermia has consistently reduced neurological deficit in animal models of traumatic brain injury when initiated pre-injury or immediately postinjury.

Posttraumatic secondary insults, especially hypoxia ${ }^{12}$ and hypotension, ${ }^{13}$ exacerbate neuronal injury and can lead to worse outcome. The results of experimental studies have, however, been conflicting. The protective effect of hypothermia $\left(30^{\circ} \mathrm{C}\right)$ initiated 15 minutes postinjury and lasting for 60 minutes in the setting of secondary insult following sTBI was demonstrated by Yamamoto. ${ }^{14}$ An impact-acceleration model of diffuse sTBI followed by 10 or 30 minutes of hypoxia to a mean $\mathrm{PaO}_{2}$ of 43.8 - $46.2 \mathrm{~mm} \mathrm{Hg}$ and hypotension (mean arterial pressure $30 \mathrm{~mm}$ $\mathrm{Hg}$ ) in male Sprague-Dawley rats was used. Hypothermia provided nearly complete protection against this secondary insult, in spite of using such a brief period of hypothermia. However, Robertson et $\mathrm{al}^{15}$ failed to find a benefit of hypothermia $\left(32^{\circ} \mathrm{C}\right.$ for four hours) in preventing secondary insult (30 minutes of hypoxemia to a $\mathrm{PaO}_{2}$ of $46-51 \mathrm{~mm} \mathrm{Hg}$ ) following severe sTBI using a controlled cortical injury model in rats. Robertson's model produces a focal contusion while Yamamoto's model produces a diffuse injury. The difference in models, particularly the incidence of irreversible injury due to the initial trauma, may account for the conflicting results. Further, Robertson used a greater duration of cooling but did not cool to the same degree. Currently, no firm conclusions can be made regarding the effect of therapeutic hypothermia on neurological outcome following secondary insult in experimental models.

\section{MECHANISMS OF CEREBRAL PROTECTION}

The cerebral protection afforded by therapeutic hypothermia in experimental models was initially attributed to the balancing of cerebral oxygen demand with supply. In 1961, Bering ${ }^{16}$ demonstrated hypothermia reduced cerebral metabolic rate for $\mathrm{O}_{2}\left(\mathrm{CMRO}_{2}\right)$ in a nonlinear fashion in monkeys. It was shown $\mathrm{CMRO}_{2}$ at $19^{\circ} \mathrm{C}$ was less than one tenth the rate at $37^{\circ} \mathrm{C}$. More recently, using ${ }^{31} \mathrm{P}$ magnetic resonance spectroscopy, Sutherland et $\mathrm{al}^{17}$ demonstrated the inorganic phosphate $\left(\mathrm{P}_{\mathrm{i}}\right)$ peak, originating from the hydrolysis product of both adenosine triphosphate and phosphocreatine, increased more rapidly at higher temperatures when compared with hypothermic rats $(\mathrm{p}<0.001)$ in a model of cerebral ischemia. The same group used nuclear magnetic resonance spectroscopy to follow glucose as it was metabolized through the glycolytic and tricarboxylic acid pathways in a rat model. ${ }^{18}$ Hypothermia resulted in 30-40\% depression of metabolism, but an upregulation of the percentage of glucose diverted through the potentially protective pentose shunt. Tissue $\mathrm{PO}_{2}$ within the brain is reduced at hypothermic temperatures, ${ }^{19}$ and hypothermia produces a low $\mathrm{CBF} / \mathrm{CMRO}_{2}$ ratio (relative ischemia). ${ }^{8}$ Although hypothermia is associated with a reduced cerebral metabolic rate, a simple reduction in metabolic rate has yet to be proven as the mechanism of cerebral protection.

Excitatory neurotransmitters, which may potentiate secondary insult following sTBI, may be beneficially modulated by therapeutic hypothermia. Once again, results from experimental studies are conflicting. Palmer et $\mathrm{al}^{4}$ used a controlled cortical impact rat model to investigate the effect of thirty minutes of pretraumatic hypothermia followed by two hours of posttraumatic hypothermia on the immediate increase in interstitial concentrations of aspartate and glutamate. Despite showing the volume of the resultant lesion was smaller in those rats treated with hypothermia compared to normothermic controls, hypothermia did not attenuate the posttraumatic rise in glutamate or aspartate. However, Globus et $\mathrm{al}^{20}$ demonstrated posttraumatic hypothermia $\left(30^{\circ} \mathrm{C} \times 3 \mathrm{~h}\right)$ attenuated glutamate release following lateral F-PTBI in rats. In contrast, Koizumi et $\mathrm{al}^{21}$ found increases in cortical levels of glutamate, aspartate, glycine and taurine after contusion in a rat weight-drop cerebral contusion model were greater in the hypothermic than in the normothermic rats. It is unclear which aspects of the differing methodologies account for the discrepant results.

Not surprisingly, the results of clinical studies have also been discrepant. Some have shown an attenuation of excitatory neurotransmitters by therapeutic hypothermia, ${ }^{22-24}$ while others 
have not. ${ }^{25}$ Thus, hypothermic modulation of excitatory neurotransmitters remains to be proven as a mechanism of neuroprotection in sTBI.

Cerebral edema is a common occurrence following severe traumatic brain injury and can lead to intracranial hypertension unless enough cerebrospinal fluid and venous blood is displaced by the oedematous portions of the brain as dictated by the Monro-Kellie doctrine. ${ }^{26}$ Since hypothermia is so potent in reducing intracranial pressure it is natural to postulate that hypothermia's benefit may be related to the control of cerebral edema and subsequent intracranial hypertension.

In 1955, following pioneering experiments in dogs on the use of hypothermia for cardiac surgery by William Bigelow, ${ }^{27}$ Rosomoff andGilbert ${ }^{28}$ observed brain volume is reduced by $4.1 \%$ and the available intracranial extra-cerebral space is increased by $31.8 \%$ in hypothermic dogs at $25^{\circ} \mathrm{C} .{ }^{28}$

Laskowski et $\mathrm{al}^{29}$ studied three groups of cats subjected to experimental traumatic brain injury. The first group served as a normothermic control $\left(37^{\circ} \mathrm{C}\right)$. The second group was subjected to hypothermia $\left(28^{\circ} \mathrm{C}\right)$ prior to the traumatic injury and maintained between 26 and $28^{\circ} \mathrm{C}$ for six hours. The third group was maintained at $37^{\circ} \mathrm{C}$ until six hours after the insult. These animals were then cooled to $25-26^{\circ} \mathrm{C}$ for 42 hours. Six hours of hypothermia markedly attenuated the histological evidence of edema in the white matter subjacent to the lesioned cortical gyrus. The astrocytes were less swollen and distended. Interestingly, the peak occurrence of edema-related changes was delayed in the second group (48 hours) compared to the normothermic controls ( 24 hours). However, the maximal changes related to edema in hypothermic animals were always substantially less pronounced than those of the normothermic group. This finding was substantiated by Ebmeyer et $\mathrm{al}^{9}$ who studied resuscitative hypothermia $\left(31^{\circ} \mathrm{C}\right)$ in a dog model of traumatic brain injury. Therapeutic hypothermia delayed the time to rise in intracranial pressure (ICP) following traumatic insult. In addition, mean ICP values were significantly higher in the normothermic groups than the hypothermic group to 48 hours. Although these studies suggest hypothermia attenuates and delays the time course of edema formation, the pathophysiology of this reduction remains to be elucidated.

The effect of therapeutic hypothermia on the blood-brain barrier (BBB) has been investigated. In the aforementioned study by Laskowski, ${ }^{29}$ the effect of hypothermia on the BBB was investigated using $10 \%$ sodium fluorescein administered $45-$ to $60 \mathrm{~min}$ before sacrifice. After 24 hours, animals with lesions produced under hypothermia showed a markedly smaller area of fluorescence indicating less disruption of the BBB. The degree of BBB disruption seen at 48 hours of delayed (six hours) hypothermia was similar to that seen at six hours of normothermia. Smith and Hall ${ }^{30}$ assessed the effects of mild cerebral hypothermia on BBB permeability in rats following a controlled cortical impact injury. Rat brain temperature was either maintained at normothermia or allowed to float freely. This resulted in mild cerebral hypothermia following injury. A secondary insult of hypotension $(0,15$, or 30 minutes to mean arterial pressure of $50 \mathrm{~mm} \mathrm{Hg}$ ) was incorporated into the model. Blood-brain barrier permeability was measured by the extravasation of Evans blue dye into the cortex at 60 minutes postinjury. The maximal hypothermic response was $-1.2^{\circ} \mathrm{C}$, - $1.6^{\circ} \mathrm{C}$ and $-1.2^{\circ} \mathrm{C}$ in the 0,15 and 30 minute hypotension groups. Brain temperature returned to baseline within 45 minutes in all groups. Relative to normothermic controls, Evans blue dye extravasation in the injured cortex was attenuated by 28.0, 21.8, and $26.2 \%$ at 0,15 and 30 minutes of hypotension, respectively. Thus, they found hypothermia provided a similar degree of BBB protection at each duration of hypotension. In addition, they also showed hypotension did not exacerbate the posttraumatic increase in $\mathrm{BBB}$ permeability. This study demonstrated the importance of small reductions in brain temperature with respect to $\mathrm{BBB}$ protection. Sutherland et $\mathrm{al}^{17}$ has shown moderate hypothermia facilitates the restoration of tissue $\mathrm{pH}$ to preischemic levels following transient forebrain ischemia in rats. This may attenuate the release of free iron from ferritin/transferrin storage sites. Free iron has a catalytic effect on oxygen radical generation. These oxygen radicals likely play a significant role in the BBB damage observed following sTBI.

Studies of free radical scavengers (superoxide dismutase) and lipid antioxidants (methylprednisolone, tirilazad mesylate) have shown these agents attenuate posttraumatic pathophysiology and/or promote survival and recovery in experimental sTBI. The effect of hypothermia on formation of free radicals has been investigated by Globus et al. ${ }^{20}$ They described the formation of hydroxyl radical formation following F-P injury in a rat model by utilizing microdialysis coupled with a salicylate-trapping method to measure 2,3- and 2,5-dihydroxybenzoic acid, which are markers of hydroxyl radical formation. Rats were subjected to sTBI followed by three hours of normothermia or hypothermia $\left(30^{\circ} \mathrm{C}\right)$. A control group not subjected to sTBI was also included. They demonstrated hydroxyl radical production lasts one to two hours following trauma. Importantly, posttraumatic hypothermia resulted in significant suppression of the increase in both 2,3- and 2,5-dihydroxybenzoic acid $(\mathrm{p}=0.001)$ following injury. They also showed the magnitude of glutamate release correlated with the extent of hydroxyl radical production, suggesting the two responses are interconnected.

The participation of inflammation in the pathophysiology of sTBI was demonstrated by Toulmond et $\mathrm{al}^{31}$ who demonstrated neuronal damage attenuation following experimental sTBI with an IL-1 $\beta$ receptor antagonist. Further, Holmin et $\mathrm{al}^{32}$ demonstrated delayed (4-6 days) strong IL-1 $\beta$, TNF- $\alpha$, and IL-6 mRNA expression surrounding the contusion produced by controlled cortical injury in the rat. Expression of IFN- $\gamma$ was not detected. Goss et $\mathrm{al}^{33}$ observed four hours of whole body hypothermia $\left(32^{\circ} \mathrm{C}\right)$, applied immediately after sTBI, attenuated the posttraumatic increase in IL- $1 \beta$ mRNA and eliminated the increase in nerve growth factor (NGF) mRNA and protein observed in cerebral cortex following STBI in a rat model. Using a controlled cortical impact model in rats, Whalen et $\mathrm{al}^{34}$ observed neutrophil accumulation in injured brain was significantly decreased in rats maintained at $32^{\circ} \mathrm{C}$ vs $39^{\circ} \mathrm{C}(4-$ fold difference as assessed by immunohistochemistry, 8-fold difference as assessed by myeloperoxidase assay). The neutrophil accumulation seemed independent of E-selectin or ICAM-1 expression or systemic absolute neutrophil count. Chatzipanteli et $\mathrm{al}^{35}$ confirmed Whalen's results by showing posttraumatic hypothermia $\left(30^{\circ} \mathrm{C} \quad \mathrm{x} \quad 3 \mathrm{~h}\right)$ reduced myeloperoxidase activity in the injured and noninjured cortical and subcortical segments compared to normothermic controls in 
F-P injury rat model. It is unclear whether inflammatory modulation by hypothermia is secondary to a reduction in the primary injury or specific inhibition of neutrophils. The latter is suggested by the increased incidence of pneumonia in those exposed to therapeutic hypothermia.

In addition to the above mechanisms, inhibition of apoptosis ${ }^{36}$ and reduction of axonal injury ${ }^{37}$ have also been described with the use of therapeutic hypothermia. The multitude of mechanisms identified suggests our understanding of the pathophysiology of sTBI and its modulation by therapeutic hypothermia is still in its infancy. The pathophysiology is clearly extremely complex and more work will be required to fully elucidate it and understand the effects of temperature modulation.

\section{REWARMING}

Although the safety consideration during rewarming has received attention, unfortunately very little work exists detailing the optimum parameters for neuroprotection during rewarming. A recent study by Suehiro ${ }^{38}$ used Sprague-Dawley rats subjected to an impact-acceleration model of sTBI to investigate the rewarming phase after use of therapeutic hypothermia. Animals were rewarmed after one hour of hypothermia to normothermia over 20 or 90 minutes. At 24 hours, amyloid precursor protein, a marker of axonal injury, was significantly reduced in those rats subjected to slower warming. In the aforementioned study by Laskowski et al, ${ }^{29}$ the degree of edema in group 3 (normothermia for six hours followed by cooling to $25-26^{\circ} \mathrm{C}$ for 42 hours) after rewarming closely resembled that seen at six hours in the normothermic controls. Thus, it appeared if the edema became "frozen" at the point in time the hypothermia was initiated. In addition, in the study by Ebmeyer et $\mathrm{al}^{9}$ mortality in the two groups was similar as ICProse to levels producing brain death in six of ten dogs in the hypothermia group, but only after rewarming. This highlights the importance of the rewarming phase since the final outcome of the edema is likely determined at this time.

\section{OPTIMALTEMPERATURE}

The optimal depth of hypothermia has not been defined. In a model of cerebral ischemia in rats, Busto ${ }^{39}$ demonstrated the critical importance of intra-ischemic brain temperature, CA1 neurons being consistently damaged at $36^{\circ} \mathrm{C}$ but not at $34^{\circ} \mathrm{C}$. In the dorsolateral striatum, ischemic cell damage was present in $100 \%$ of the hemispheres at $36^{\circ} \mathrm{C}$ but only in $50 \%$ of the hemispheres at $34^{\circ} \mathrm{C}$. Effects of hypothermia were more pronounced in the central zone of the striatum where no rat at $34^{\circ} \mathrm{C}$ had ischemic neurons, whereas all rats at $36^{\circ} \mathrm{C}$ had damage in this area. Virtually no ischemic cell change was noticed in any region in those rats whose intraischemic temperature fell to 30 $31^{\circ} \mathrm{C}$. This beneficial effect of hypothermia may be mediated through the modulation of excitatory neurotransmitters as the release of glutamate was completely inhibited and the release of dopamine was attenuated by $60 \%$ in animals whose brain temperature was maintained at $33^{\circ} \mathrm{C}$ and $30^{\circ} \mathrm{C}$.

It should be noted that this model was one of ischemia, not traumatic brain injury. Although ischemic injury is common following sTBI, ${ }^{40,41}$ sTBI involves diffuse shearing injury, focal contusion, hemorrhage, and secondary focal and global ischemia. Therefore, the generalization of results from pure ischemic models to traumatic brain injury must be done with caution since traumatic brain injury has so many more components than just ischemia. However, Pomeranz et $\mathrm{al}^{10}$ used a dog model of epidural hematoma and demonstrated benefit, with respect to the volume of damaged brain tissue, of moderate hypothermia. Interestingly, the intraventricular pressure rise following injury was prevented by moderate $\left(31^{\circ} \mathrm{C}\right)$ but not mild hypothermia $\left(35^{\circ} \mathrm{C}\right)$. Mori and colleagues ${ }^{8}$ exposed cats to a deep-brain temperature of $37^{\circ} \mathrm{C}$ (control), $33^{\circ} \mathrm{C}$ (mild hypothermia), or $29^{\circ} \mathrm{C}$ (moderate hypothermia) following compression injury. Mild hypothermia showed coupled CBFmetabolic suppression, but moderate hypothermia resulted in disproportionately increased arterial-venous oxygen difference and a low ratio of cerebral blood flow to $\mathrm{CMRO}_{2}$ suggesting relative ischemia.

Although the above suggests the ideal temperature may lie between $34^{\circ} \mathrm{C}$ and $29^{\circ} \mathrm{C}$, a recent study of the effect of temperature on brain parenchymal oxygenation $\left(\mathrm{PbtO}_{2}\right)$ suggests temperatures below $35^{\circ} \mathrm{C}$ may not be ideal. Gupta et $\mathrm{al}^{19}$ studied 30 patients with sTBI. There was a significant decrease in $\mathrm{PbtO}_{2}$ below $35^{\circ} \mathrm{C}(\mathrm{p}<0.05)$ with a highly significant reduction below $34^{\circ} \mathrm{C}(\mathrm{p}<0.001)$ compared with $37^{\circ} \mathrm{C}$. Brain tissue $\mathrm{CO}_{2}$ also decreased with hypothermia without significant effect on tissue $\mathrm{pH}$. The authors suggested the neuroprotective effects of induced hypothermia may be most beneficial at $35^{\circ} \mathrm{C}$ as cerebral oxygenation is impaired below this level. However, a similar study by Soukup et $\mathrm{al}^{24}$ studied the effect of mild hypothermia $\left(34-36^{\circ} \mathrm{C}\right)$ on brain tissue oxygen tension, carbon dioxide tension tissue, and $\mathrm{pH}$ using a multi-parameter probe in 33 selected patients with sTBI. Mild induced hypothermia decreased brain oxygen significantly from $33 \pm 24 \mathrm{~mm} \mathrm{Hg}$ to $30 \pm 22 \mathrm{~mm} \mathrm{Hg}$ $(\mathrm{p}<0.05)$. The brain tissue $\mathrm{CO}_{2}(46 \pm 8 \mathrm{~mm} \mathrm{Hg})$ was also significantly lower during mild hypothermia $(40.4 \pm 4.0 \mathrm{~mm} \mathrm{Hg}$, $\mathrm{p}<0.0001)$. In contrast to the results from Gupta's study, the tissue $\mathrm{pH}$ increased from $7.13 \pm 0.15$ to $7.24 \pm 0.10 \quad(\mathrm{p}<0.0001)$ under hypothermic conditions. The identification of an increased brain tissue $\mathrm{pH}$ despite decreased tissue oxygenation by Soukup suggests the critical hypoxic threshold is reduced by induction of hypothermia which decreases anaerobic metabolism. Thus, the determination of the optimal depth of therapeutic hypothermia awaits further research.

\section{Clinical studies}

Much excitement was generated following the publication of several small single centre studies that suggested therapeutic hypothermia was beneficial to those with sTBI. ${ }^{23,42,43}$ The largest of these studies was undertaken at the University of Pittsburgh. Marion et $\mathrm{al}^{23}$ randomized 82 patients with a Glasgow Coma Scale (GCS) 3-7 to hypothermia $\left(32-33^{\circ} \mathrm{C}\right)$ or normothermia for 24 hours. Patients had to be admitted within six hours of injury. Patients were rewarmed at a rate of no more than $1^{\circ} \mathrm{C}$ per hour to $37-38.5^{\circ} \mathrm{C}$. Outcome was assessed by a physiatrist blinded to treatment allocation. There was no difference in mortality between the two groups. At 12 months, the proportion of patients with a good neurological outcome (Glasgow outcome score 4 or $5)$ was higher in the hypothermia group (62\% vs. $38 \%, \mathrm{p}=0.05)$. This benefit was primarily due to those patients with an initial 
Table 2: Recent randomized controlled trials of therapeutic hypothermia in severe traumatic brain injury

\begin{tabular}{|c|c|c|c|c|c|c|c|c|}
\hline Trial & Multicentre? & $\begin{array}{l}\text { Total Number } \\
\text { of Patients }\end{array}$ & $\begin{array}{l}\text { Temperature } \\
\text { Goal }\left({ }^{\circ} \mathrm{C}\right)\end{array}$ & $\begin{array}{l}\text { Duration of } \\
\text { Hypothermia }\end{array}$ & $\begin{array}{l}\text { Mortality } \\
\text { Treatment } \\
\text { Group }\end{array}$ & $\begin{array}{l}\text { Mortality } \\
\text { Control } \\
\text { Group }\end{array}$ & $\begin{array}{l}\text { Favourable Neuro- } \\
\text { logical Outcome } \\
\text { Treatment Group }\end{array}$ & $\begin{array}{l}\text { Favourable Neuro- } \\
\text { logical Outcome } \\
\text { Control Group }\end{array}$ \\
\hline Jiang $^{46}$ & No & 87 & $33-35$ & 3-14 days & $25.5 \%$ & $45.5 \% *$ & $46.5 \%$ & $27.3 \% *$ \\
\hline Aibiki $^{45}$ & No & 26 & $32-33$ & 3-4 days & $6.6 \%$ & $27.3 \%$ & $80 \%$ & $36.4 \% *$ \\
\hline Shiozaki $^{44}$ & Yes & 91 & $33.5-34.5$ & $48 \mathrm{~h}$ & $17 \%$ & $13 \%$ & $46 \%$ & $58 \%$ \\
\hline
\end{tabular}

$* \mathrm{p}<0.05, \# \mathrm{p}=0.05$

GCS of 5-7 as those with an initial GCS of 3-4 did not benefit from hypothermia. Hypothermia was not associated with an increased incidence of pneumonia. Since the publication of this study, five randomized studies of the use of therapeutic hypothermia in sTBI have been fully published and are summarized here. (See Table 2.)

In two studies, Shiozaki et $\mathrm{al}^{25,44}$ found the use of hypothermia ineffective in the treatment of patients with sTBI whose ICP could be controlled by conventional means. The conventional means of controlling ICP included mild hyperventilation, ventricular CSF drainage, osmotic agents and barbiturates but was not reported to be protocolized. The first study involved only 12 patients. The second study of similar methodology was multicentre in nature and included a total of 91 patients. In this study, if the ICP remained $<25 \mathrm{~mm} \mathrm{Hg}$ after conventional ICP measures were implemented, patients were randomized to 48 hours of hypothermia or normothermia. No overall effect of hypothermia in terms of three-month Glasgow outcome score was found in either study. Infection, particularly pneumonia, was more common in the hypothermia group. Prior to Marion's publication, the same authors studied those with persistent intracranial hypertension despite conventional ICP control methods and high dose barbiturates. ${ }^{42}$ Thirty-three patients were randomized to cooling to $33.5-34^{\circ} \mathrm{C}$ for a minimum of 48 hours and until ICP was below $20 \mathrm{~mm} \mathrm{Hg}$ for 24 hours or no active temperature management. Eight patients $(50 \%)$ in the hypothermia group and three $(18 \%)$ in the control group survived $(\mathrm{p}<0.05)$.

Aibiki and colleagues ${ }^{45}$ randomized 26 patents with sTBI to hypothermia $\left(32-33^{\circ} \mathrm{C}\right)$ or normothermia $\left(36-37^{\circ} \mathrm{C}\right)$. Therapy was initiated three to four hours after injury. The duration of hypothermia usually lasted for three to four days, after which the patients were rewarmed at a rate of approximately $1^{\circ} \mathrm{C}$ per day. Mean Glasgow outcome score at six months was significantly better in the hypothermia group [normothermia, 2.9 \pm 0.5 ; hypothermia, $4.2 \pm 0.3$ ( $\mathrm{p}<0.05$ ].

Jiang et $\mathrm{al}^{46}$ published a trial of prolonged hypothermia in sTBI. In this single centre trial, 87 patients were randomized to hypothermia $\left(33-35^{\circ} \mathrm{C}\right)$ or normothermia. Patients were maintained hypothermic until ICP returned to normal $(<15 \mathrm{~mm}$ $\mathrm{Hg}$ ) which ranged from 3 to 14 days. Patients were rewarmed at a rate $\leq 1{ }^{\circ} \mathrm{C}$ per hour. Blinded outcome analysis revealed hypothermia to significantly reduce mortality ( $25.5 \%$ vs. $45.5 \%$, $\mathrm{p}<0.05)$ and improve favourable outcome $(46.5 \%$ vs. $27.3 \%$, $\mathrm{p}<0.05)$. There was no difference in the incidence of pneumonia or other complications.

Clifton ${ }^{47}$ published the largest multicentre trial of therapeutic hypothermia in sTBI. A total of 392 patients with sTBI (GCS 38) were randomized to hypothermia $\left(32.5-34^{\circ} \mathrm{C}\right)$ or normothermia for 48 hours. The mean time from injury to the achievement of the target temperature of $33^{\circ} \mathrm{C}$ in the hypothermia group was $8.4 \pm 3.0$ hours. Patients were rewarmed at a rate no faster than $0.5^{\circ} \mathrm{C}$ every two hours. Overall, hypothermia had no significant effect on the proportion of patients with a poor neurological outcome (severe disability, vegetative state or death) or mortality. However, the patients treated with hypothermia had a higher incidence of critical hypotension. Hypotension in the setting of sTBI is a wellestablished negative prognostic factor and may have partially accounted for the lack of benefit seen in this study. In the subgroup of older patients ( $>45$ years of age), there was a trend towards worse outcome with the use of hypothermia. Temperature at admission was found to be an important determinant of outcome. Specifically, among patients 45 years of age or younger who had hypothermia on admission, 52 percent of those assigned to the hypothermia group had poor outcomes, as compared with 76 percent in the normothermia group $(\mathrm{P}=0.02)$. Further analysis of this trial has suggested a significant intra-centre variation in baseline, physiological and treatment variables. ${ }^{48}$ Thus, variability with respect to co-interventions may also have had an unmeasured confounding effect.

The Cochrane group has recently updated their meta-analysis of the use of therapeutic hypothermia in STBI. ${ }^{49}$ Hypothermia was not associated with a significant reduction in the odds of death at the end of treatment or final follow-up (OR 0.88, 95\% CI: 0.63-1.21). For death or severe disability, again hypothermia was not associated with a significant reduction in the odds of being dead or severely disabled at final follow-up (OR 0.75, 95\% CI: 0.56-1.00). However, hypothermia treatment was associated with a statistically significant increase in the odds of pneumonia (OR 1.95, 95\% CI:1.18-3.23).

\section{THE FUTURE OF HYPOTHERMIA}

Who benefits from therapeutic hypothermia? What is the optimal depth of hypothermia? What is the optimal duration of 
hypothermia? What is the optimal rewarming technique? Although hypothermia has been shown to be beneficial in terms of neurological outcome in animal models, and this benefit has been seen in various models of injury and across species, the clinical evidence remains inconclusive. No study has shown hypothermia to be beneficial in the older patient ( $>45$ years old). Moreover, there appears to be a suggestion of harm in this subgroup. Thus, treatment of the older patient with hypothermia is not recommended. Current evidence suggests a subgroup that may benefit from hypothermia. Further investigation should focus on the younger patient with an admission GCS of 5-8 who is at high risk for intracranial hypertension.

The positive effect of prolonged hypothermia seen in the studies by Aibili, Jiang and Shiozaki suggests 24-48 hours of therapy may not be adequate. Indeed, it may be harmful to rewarm those with reduced intracranial compliance. Therefore, future studies should explore the effect of longer treatment regimens. Many studies using too short a cooling period may give spurious, false-negative results. Attention to slow rewarming is also critical, based on the animal data.

Because we want results we can generalise, trials should be multicentre in nature. However, there appears to be inter-centre differences such that participating centres should have experience in the technique and enrol significant numbers of patients. This may be particularly important in the prevention, early identification, and management of complications. Careful attention to co-interventions and compliance to standardized treatment protocols is essential. Despite a recent editorial suggesting therapeutic hypothermia has been "proved ineffective", such a declaration is probably premature in view of the multiple parameters involved (treatment delay, treatment duration, depth of hypothermia, rewarming parameters). In fact, few therapies used in the treatment of sTBI have been "proven" effective. ${ }^{50}$ Further, the mortality and morbidity from sTBI is substantial and hypothermia is a relatively inexpensive therapy in relation to the costs of the neurologic deficits of brain trauma. Thus, we should not abandon this therapy until we are certain the right patients are chosen and the methodology of implementation is optimal.

\section{ACKNOWLEDGEMENTS}

We thank the members of the Departments of Critical Care Medicine, Clinical Neuroscience and Pathology and Laboratory Medicine at the University of Calgary for their support. Dr. Zygun was supported by the Meredith Graduate Master's Scholarship, Workers Compensation Board of Alberta. Dr. Laupland was supported by the 2000 Bayer Healthcare/Canadian Institutes of Health Research/Canadian Infectious Diseases Society Research Fellowship and a clinical fellowship award from the Alberta Heritage Foundation for Medical Research (AHFMR).

\section{REFERENCES}

1. Kraus J, McArthur D. Epidemiology of brain injury. In: Cooper PR, Golfinos JG, (Eds). Head Injury. New York: McGraw-Hill, 2000:1-26.

2. Fay T. Observations on generalized refrigeration in cases of severe cerebral trauma. Assoc Res Nerv Ment Dis Proc 1943; 24:611619.

3. Clifton GL, Jiang JY, Lyeth BG, et al. Marked protection by moderate hypothermia after experimental traumatic brain injury. J Cereb Blood Flow Metab 1991;11:114-121.

4. Palmer AM, Marion DW, Botscheller ML, Redd EE. Therapeutic hypothermia is cytoprotective without attenuating the traumatic brain injury-induced elevations in interstitial concentrations of aspartate and glutamate. J Neurotrauma 1993;10:363-372.

5. Lyeth BG, Jiang JY, Robinson SE, Guo H, Jenkins LW. Hypothermia blunts acetylcholine increase in CSF of traumatically brain injured rats. Mol Chem Neuropathol 1993;18:247-256.

6. Dietrich WD, Feng ZC, Leistra H, Watson BD, Rosenthal M. Photothrombotic infarction triggers multiple episodes of cortical spreading depression in distant brain regions. J Cereb Blood Flow Metab 1994;14:20-28.

7. Bramlett HM, Green EJ, Dietrich WD, et al. Posttraumatic brain hypothermia provides protection from sensorimotor and cognitive behavioral deficits. J Neurotrauma 1995;12:289-298.

8. Mori K, Maeda M, Miyazaki M, Iwase H. Effects of mild (33 degrees C) and moderate (29 degrees C) hypothermia on cerebral blood flow and metabolism, lactate, and extracellular glutamate in experimental head injury. Neurol Res 1998;20:719-726.

9. Ebmeyer U, Safar P, Radovsky A, et al. Moderate hypothermia for 48 hours after temporary epidural brain compression injury in a canine outcome model. J Neurotrauma 1998;15:323-336.

10. Pomeranz S, Safar P, Radovsky A, et al. The effect of resuscitative moderate hypothermia following epidural brain compression on cerebral damage in a canine outcome model. J Neurosurg 1993;79:241-251.

11. Clasen RA, Pandolfi S, Stuart D, Russell JL. Hypothermia and hypotension in experimental cerebral injury. J Neuropathol Exp Neurol 1968;27:127-128.

12. Bramlett HM, Dietrich WD, Green EJ. Secondary hypoxia following moderate fluid percussion brain injury in rats exacerbates sensorimotor and cognitive deficits. J Neurotrauma 1999;16:1035-1047.

13. Matsushita Y, Bramlett HM, Alonso O, Dietrich WD. Posttraumatic hypothermia is neuroprotective in a model of traumatic brain injury complicated by a secondary hypoxic insult. Crit Care Med 2001;29:2060-2066.

14. Yamamoto M, Marmarou CR, Stiefel MF, Beaumont A, Marmarou A. Neuroprotective effect of hypothermia on neuronal injury in diffuse traumatic brain injury coupled with hypoxia and hypotension. J Neurotrauma 1999;16:487-500.

15. Robertson CL, Clark RS, Dixon CE, et al. No long-term benefit from hypothermia after severe traumatic brain injury with secondary insult in rats. Crit Care Med 2000;28:3218-3223.

16. Bering E. Effect of body temperature change on cerebral oxygen consumption of the intact monkey. Am J Physiol 1961;200:417419.

17. Sutherland GR, Peeling J, Sutherland E, et al. Magnetic resonance imaging and ${ }^{31} \mathrm{P}$ spectroscopy study of the effect of temperature on ischemic brain injury. Can J Neurol Sci 1992;19:317-325.

18. Kaibara T, Sutherland GR, Colbourne F, Tyson RL. Hypothermia: depression of tricarboxylic acid cycle flux and evidence for pentose phosphate shunt upregulation. J Neurosurg 1999;90:339347.

19. Gupta AK, Al-Rawi PG, Hutchinson PJ, Kirkpatrick PJ. Effect of hypothermia on brain tissue oxygenation in patients with severe head injury. Br J Anaesth 2002;88:188-192.

20. Globus MY-T, Busto R, Lin B, Schnippering H, Ginsberg MD. Detection of free radical activity during transient global ischemia and recirculation: effects of intraischemic brain temperature modulation. J Neurochem 1995;65:1250-1256.

21. Koizumi H, Fujisawa H, Ito H, et al. Effects of mild hypothermia on cerebral blood flow-independent changes in cortical extracellular levels of amino acids following contusion trauma in the rat. Brain Res 1997;747:304-312.

22. Yamaguchi S, Nakahara K, Miyagi T, Tokutomi T, Shigemori M. Neurochemical monitoring in the management of severe headinjured patients with hypothermia. Neurol Res 2000;22:657-664.

23. Marion DW, Penrod LE, Kelsey SF, et al. Treatment of traumatic brain injury with moderate hypothermia. N Engl J Med 1997;336:540-546.

24. Soukup J, Zauner A, Doppenberg EM, et al. Relationship between brain temperature, brain chemistry and oxygen delivery after 
severe human head injury: the effect of mild hypothermia. Neurol Res 2002;24:161-168.

25. Shiozaki T, Kato A, Taneda M, et al. Little benefit from mild hypothermia therapy for severely head injured patients with low intracranial pressure. J Neurosurg 1999;91:185-191.

26. Mokri B. The Monro-Kellie hypothesis: applications in CSF volume depletion. Neurology 2001;56:1746-1748.

27. Bigelow WG, Callaghan JC, Hopps JA. General hypothermia for experimental intracardiac surgery. Ann Surg 1950;132:531-537.

28. Rosomoff $\mathrm{H}$. Brain volume and cerebrospinal fluid pressure during hypothermia. Am J Physiol 1955; 183:19.

29. Laskowski E. Experimental study of the effects of hypothermia on local brain injury. Neurology 1960; 10:499-505.

30. Smith SL, Hall ED. Mild pre- and posttraumatic hypothermia attenuates blood-brain barrier damage following controlled cortical impact in the rat. J Neurotrauma 1996;13:1-9.

31. Toulmond S, Rothwell NJ. Interleukin-1 receptor antagonist inhibits neuronal damage caused by fluid percussion injury in the rat. Brain Res 1995;671:261-266.

32. Holmin S, Almqvist P, Lendahl U, Mathiesen T. Adult nestinexpressing subependymal cells differentiate to astrocytes in response to brain injury. Eur J Neurosci 1997;9:65-75.

33. Goss JR, Styren SD, Miller PD, et al. Hypothermia attenuates the normal increase in interleukin $1 \beta$ RNA and nerve growth factor following traumatic brain injury in the rat. J Neurotrauma 1995; 12:159-167.

34. Whalen MJ, Carlos TM, Clark RS, et al. The relationship between brain temperature and neutrophil accumulation after traumatic brain injury in rats. Acta Neurochir Suppl (Wien) 1997;70:260-261.

35. Chatzipanteli K, Alonso OF, Kraydieh S, Dietrich WD. Importance of posttraumatic hypothermia and hyperthermia on the inflammatory response after fluid percussion brain injury: biochemical and immunocytochemical studies. J Cereb Blood Flow Metab 2000;20:531-542.

36. Xu R-X, Nakamura $T$, Nagao $S$, et al. Specific inhibition of apoptosis after cold-induced brain injury by moderate postinjury hypothermia. Neurosurgery 1998;43:107-114.

37. Koizumi H, Povlishock JT. Posttraumatic hypothermia in the treatment of axonal damage in an animal model of traumatic axonal injury. J Neurosurg 1998;89:303-309.

38. Suehiro E, Povlishock JT. Exacerbation of traumatically induced axonal injury by rapid posthypothermic rewarming and attenuation of axonal change by cyclosporin A. J Neurosurg 2001;94:493-498.

39. Busto R, Dietrich WD, Globus MY-T, et al. Small differences in intraischemic brain temperature critically determine the extent of ischemic neuronal injury. J Cereb Blood Flow Metab 1987;7:729738.

40. Graham DI, Adams JH, Doyle D. Ischaemic brain damage in fatal non-missile head injuries. J Neurol Sci 1978;39:213-234.

41. Bouma GJ, Muizelaar JP, Stringer WA, et al. Ultra-early evaluation of regional cerebral blood flow in severely head-injured patients using xenon-enhanced computerized tomography. J Neurosurg 1992;77:360-368.

42. Shiozaki T, Sugimoto H, Taneda M, et al. Effect of mild hypothermia on uncontrolled intracranial hypertension after severe head injury. J Neurosurg 1993;79:363-368.

43. Clifton GL, Allen S, Barrodale P, et al. A phase II study of moderate hypothermia in severe brain injury. J Neurotrauma 1993;10:263271.

44. Shiozaki T, Hayakata T, Taneda M, et al. A multicenter prospective randomized controlled trial of the efficacy of mild hypothermia for severely head injured patients with low intracranial pressure. Mild Hypothermia Study Group in Japan. J Neurosurg 2001;94:50-54.

45. Aibiki M, Maekawa S, Yokono S. Moderate hypothermia improves imbalances of thromboxane $\mathrm{A}_{2}$ and prostaglandin $\mathrm{I}_{2}$ production after traumatic brain injury in humans. Crit Care Med 2000;28:3902-3906

46. Jiang J, Yu M, Zhu C. Effect of long-term mild hypothermia therapy in patients with severe traumatic brain injury: 1-year follow-up review of 87 cases. J Neurosurg 2000;93:546-549.

47. Clifton GL, Miller ER, Choi SC, et al. Lack of effect of induction of hypothermia after acute brain injury. N Engl J Med 2001;344: 556-563.

48. Clifton GL, Choi SC, Miller ER, et al. Intercenter variance in clinical trials of head trauma - experience of the National Acute Brain Injury Study: Hypothermia. J Neurosurg 2001;95:751-755.

49. Gadkary CS, Alderson P, Signorini DF. Therapeutic hypothermia for head injury. Cochrane Database Syst Rev 2002:CD001048.

50. Narayan RK. Hypothermia for traumatic brain injury - a good idea proved ineffective. N Engl J Med 2001;344:602-603. 